At present, however, such records are made in a somewhat haphazard manner. There is no deliberate effort to collect representative records of the present age, and as yet no permanent centre where such records could be stored. The 'film library', in fact, is in its infancy. Problems of storage and the whole technique of such a library have received little study. Research has revealed that in the case of negative films taken twenty years ago, the celluloid base is gradually disintegrating. It appears that an acetate base is more stable, and positives on such a base are being made as a stand-by. Evidently this question of the permanence of films of national value is one of great importance, on which further research is needed.

A considerable portion of the report is devoted to the use of films as an educational medium in schools. The film, as a means of instruction, has certain definite advantages over oral methods. It acts as a stimulant, sharpens the critical faculty, and widens the mental horizon, and may be applied to develop dissatisfaction with the inferior and the commonplace. The quality of recollection is more vivid and the impression more lasting than when facts have been presented orally.

It is suggested that films can be applied in three chief ways: ( 1 ) in the classroom for teaching, (2) for occasional demonstrations in the school hall on subjects of general interest, and (3) in public cinema theatres, where films making a special appeal to children should be exhibited. Even in such a poor country as Austria, the use of central cinema halls, to which neighbouring schools can send contingents of children, has been developed. Another device, familiar in Italy and Russia, with which experiments have been made in England, is the travelling van.

The great difficulty is that there is at present no machinery for providing contact between university and school staffs and the producer. Many teachers are anxious to obtain educational films, and there are firms willing to make a speciality of producing them ; but firms are unwilling to enter upon production without a certainty of a market, and educational authorities are reluctant, even when funds are available, to expend money in this direction without full knowledge that the film will be really suitable for their purpose.
The report contains some data on the cost of production. A feature film, as shown publicly, may cost at least $£ 2000$ a week to make and at least $£ 3$ a foot in its final form. An educational sound film might cost between $10 \mathrm{~s}$. and $30 \mathrm{~s}$, a foot, so that a reel of $1000 \mathrm{ft}$. would cost $£ 500-£ 1500$. The production of such a film demands means of linking the expert skill of the producer and technician with the professional knowledge of the specialist and the teacher.

As regards size of film, it is believed that the $9 \mathrm{~mm}$. type is only suitable for the private cinema and for research. It is expedient to aim at the use of the $16 \mathrm{~mm}$. standard for classrooms (giving a picture $5 \mathrm{ft} . \times 6 \mathrm{ft}$. or $3 \mathrm{ft} . \times 4 \mathrm{ft}$.$) , and the full size (35 \mathrm{~mm}$.) for halls when films of general interest are shown. In an appendix to the report there is a useful list of projectors, accompanied by particulars of price, pressure, wattage and price of lamps, and other data. of the types recommended for general educational use, the $16 \mathrm{~mm}$. projector costs from $£ 15$ to $£ 80$ and the $35 \mathrm{~mm}$. from $£ 60$ to $£ 150$. The latter figure would probably have to be multiplied by four if sound production apparatus were included.

The proposed National Film Institute should serve as a positive agency to encourage valuable and good films rather than discourage bad ones. Government recognition appears essential, but the Institute might be either a Government department or institute or an incorporated institute, or a combination of both. Its functions would include acting as a national clearinghouse for information and research; assisting in the preparation of film records and serving as a national repository of films of permanent value; the stimula. tion of public opinion to demand good films ; giving advice to teachers and instructors who need films in connexion with their work ; acting as a means of liaison with trade, producers, experts, cultural interests, and educators; and encouraging research. Although the present time, when demands for economy are so imperative, is scarcely opportune for advocating the formation of a National Film Institute, it is felt that ultimately the nation would receive a more than adequate return for the expenditure involved.

\title{
Jeremy Bentham, Philosopher and Social Engineer
}

THE centenary of the death of Jeremy Bentham was commemorated on June 6, at University College, London, when a public lecture was delivered by Mr. C. K. Ogden on Bentham's work.

Mr. Ogden dwelt chiefly on those aspects of Bentham's work which, in his opinion, will claim the attention of future generations. His influence on the past and his message for the present were based upon his profound analysis of the symbolic factor in every branch of human activity. Bentham's exposure of word magic was motivated partly by reflections on the fear of ghosts which dominated his childhood, and partly by a dislike of legal fictions generated by Blackstone's lectures at Oxford. It was not until after his sixtieth year, however, that he embarked on the systematic development of his theory of fictions, which anticipated Vaihinger's "Philosophie des Als Ob", as well as the modern formalistic account of mathematics. It enabled him to provide a ' technological ' account of language, such as modern science demands.

Bentham's most original contribution consisted in the elaboration of a technique of 'archetypation' by means of which the fictions of physics and psycho. logy could be translated into the basic pointing symbols, which are the archetypes of all metaphor, all fictions, and all abbreviations. He himself ex- plicitly described his social and legal theories, which had so profound an effect upon the history of the nineteenth century, as applications of the principles of experimental science in the field of economics and government. From this same point of view he championed the cause of the inventor and of technical education. His younger brother, Sir Samuel Bentham, the famous marine engineer, and his nephew, George Bentham, one of the founders of systematic botany, were as much his disciples as Ricardo and Jevons in economics or Southwood Smith and Chadwick in matters of public health.

According to Bentham, all language, all symbolic forms, must be interpreted in an operational context. Some words point at things as the hands of a clock point at the hours ; others, such as 'right ', 'faculty', 'motion', ' redness', or 'of', are like single parts or accessories of a clock. They may help us to do the pointing; but any such part taken in isolation is no more than an intriguing piece of metal about which any number of conflicting theories may be held. Put it back in its place, where it helps to perform some operation, and it can be treated functionally. Above all, we can see what substitutes are possible, either for any particular part or for any portion which operates as a unit.

No. 3268, Vou. 129] 
By neglecting the implications of the technological analysis, philosophy has become, almost entirely, the unjustifiable exploitation of the metaphorical, the fictional, and the elliptical. Bentham's method of archetypation, as shown by Prof. S. M. Buchanan's recent study, "Symbolic Distance", does all that the logico-analytical theory of 'incomplete symbols' can do, without resort to logical or mathematical jargon at any point.

Bentham's interest in re-formulation found expression in his powerful advocacy of codification, a word which, like 'international ', 'maximise ', 'minimise ', etc., he himself introduced. But the most significant application of Benthamic principles is in connexion with the problem of a universal (auxiliary) language.

Mr. Ogden explained how, by developing certain suggestions put forward by Bentham, he had succeeded in formulating a system whereby 850 English words could be used to take the place of a normal vocabulary of 20,000 , for all the purposes of everyday life, general talk, news, trade, and science. To the eye and ear this system, known as 'Basic English', is scarcely distinguishable from standard English; indeed, for some five minutes, Mr. Ogden made use only of 'Basic English', a fact of which the audience was unaware until they were informed of it.

Mr. Ogden concluded with a plea for a more careful study of Bentham's neglected manuscripts and of the symbolic material printed in his posthumous works. It was Talleyrand who said of Bentham, " Though all the world has stolen from him, he is still rich" ; and to the inventor and experimenter of the future he may well appear as the founder of a new science, which might be appropriately christened 'Orthology'-the systematic analysis and ordering of symbols at the level of ordinary communication.

\section{Calendar of Geographical Exploration}

June 19, I908.--Northern Arabia

Alois Musil arrived at Damascus, whence he made surveying expeditions and reached Resafe, 12 miles from the Euphrates, the most northerly point which he visited. Resafe is of great interest because of its ruined churches and palaces and its Greek, Aramaic, and Arabic inscriptions. By several journeys Musil made a plane table survey of the whole region. $\mathrm{He}$ made other journeys in face of great difficulties; his work resulted in the preparation of a map of northern Arabia, including the district from $37^{\circ}$ to $44^{\circ} \mathrm{E}$. long. and from $36^{\circ}$ to $27^{\circ} \mathrm{N}$. lat. Important additions to the map of Arabia Petræa were made, and much new knowledge of the ethnography, linguistics, and natural history of northern Arabia was gained.

\section{June $2 \mathrm{I}, \mathrm{I} 764 .-$ The Falkland Islands}

Commodore John Byron, who had taken part twentyfive years before in Anson's circumnavigation, sailed from the Downs to look for islands or lands between the Cape of Good Hope and the Strait of Magellan. His voyage was the first of a series which widened the knowledge of the Pacific. Byron reached the Falkland Islands and took possession of them for King George III., though a French colony had been settled there in the previous year by Bougainville. The islands were discovered by John Davis in 1592 and known as John Davis's South Land. In 1690, John Strong discovered the strait between the two main islands and named it Falkland Sound, the name Falkland being transferred to the whole group by Byron. Byron then discovered the Islands of Disappointment to the north of the Low Archipelago, King George's
Island, and Nukunau or Byron Island in the Gilbert group, ultimately reaching England in 1766 .

\section{June 2I, I882.-Alexandra Land}

B. Leigh Smith, who had previously made three journeys to Spitsbergen, set off with his party to try to reach some vessels off Novaya Zemlya. Leigh Smith had set out in the Eira, a steam yacht, in 1880, had sailed along the south side of Franz Josef Land to the west, and had discovered 110 miles of coastline of a new island named Alexandra Land. In 1881, Leigh Smith sailed again for Franz Josef Land, but the vessel was caught in the ice and sank. The party built a hut and wintered on the shore, setting off in boats on the date given above. They were met by the Willem Barents, a Dutch vessel which made annual polar explorations for many years.

\section{June 22, 1878.- Voyage of the Vega}

A. E. Nordenskiöld left Karlskrona in the Vega for his famous voyage round Asia and Europe. The Vega sailed through the polar seas off northern Siberia and passed through Bering Strait, "thus after the lapse of 336 years [since Willoughby's voyage] and when most men experienced in navigation had declared the undertaking impossible, was the north-east passage achieved ". Nordenskiolld had previously reached the mouth of the Yenisei in 1875 in a walrus-hunting sloop, the Proeven, and again in a steamer, the $Y$ mer, in 1876. His preparations for the voyage of 1878 were very thorough and included a study of the records of previous travellers in various regions of northern Siberia, chiefly from the point of view of the condition of the ice and the direction of the wind at various dates in different years. The Lena, which had accompanied the Vega, parted from it at the delta of the Lena River about Aug. 27-28 and steamed to Yakutsk, the first vessel from the northern ocean to reach the heart of Siberia. The Vega proceeded eastwards to $67^{\circ} 4^{\prime} \mathrm{N}$. and $173^{\circ} 23^{\prime} \mathrm{W}$., when she was shut in by ice on Sept. 29, and the party had to spend the winter there. The diet had been carefully thought out and the health of the party remained good, no case of scurvy occurring, nor was there any case of serious frostbite. Meteorological observations were taken every four hours up to Nov. 1, after that date every hour up to April 1, and then again every four hours. Friendly relations were established with the Chukchi, and during the 10 months' winter much useful ethnographical and linguistic information was collected. The Vega sailed on July 18 from its winter home and sighted East Cape (now Cape Dezhnev) on July 20. Data about the Eskimo at Port Clarence were collected, a survey of Bering Strait was made, Bering Island was visited and described, and attempts were made to record the date of extinction of Steller's sea cow (Rhytina Stelleri, Cuvier), which was abundant on the island when Bering and Steller were wrecked there. The Vega then proceeded to Japan, and afterwards returned to Europe via Ceylon, Aden, and the Suez Canal. The voyage was remarkable for the care with which it was organised, and for the masses of scientific data collected by the distinguished group who accompanied Nordenskiöld, as well as for its pioneer geographical character.

\section{June 24, 1339.-An Early Traveller to China and the East}

John Marignolli, a Florentine missionary, left Kaffa, whence he went overland to Kulja and Peking. He stayed four years in China, returning by sea. He describes southern China, gives glowing accounts of the beauties of Ceylon, and mentions Ormuz as a great market town. His descriptions of his overland journey 